Article

\title{
The Optimum Window-to-Wall Ratio in Office Buildings for Hot-Humid, Hot-Dry, and Cold Climates in Iran
}

\author{
Jalil Shaeri ${ }^{1, * \mathbb{D}}$, Amin Habibi ${ }^{1, * \mathbb{D}}$, Mahmood Yaghoubi ${ }^{2} \mathbb{D}$ and Ata Chokhachian ${ }^{3, * \mathbb{D}}$ \\ 1 Faculty of Arts and Architecture, Shiraz University, Shiraz 718773-35, Iran \\ 2 School of Mechanical Engineering, Shiraz University, Shiraz 7196481334, Iran; yaghoubi@shirazu.ac.ir \\ 3 Chair of Building Technology and Climate Responsive Design, Technical University of Munich, \\ 80333 Munich, Germany \\ * Correspondence: jalil.shaeri@shirazu.ac.ir (J.S.); a_habibi@shirazu.ac.ir (A.H.); \\ ata.chokhachian@tum.de (A.C.)
}

Received: 2 February 2019; Accepted: 8 April 2019; Published: 16 April 2019

\begin{abstract}
About half of the energy loss in buildings is wasted through windows. Determining the optimum window-to-wall ratio (WWR) for different building facades would reduce such energy losses. The optimum WWR is the window area that minimizes the total annual energy of cooling, heating, and lighting. The purpose of this study is to investigate the optimum WWR of different facades of an office building. For this purpose, a sample building is simulated by means of DesignBuilder software in order to investigate the annual solar heat gain, cooling load, heating load, and lighting consumption for the three cities of Bushehr, Shiraz, and Tabriz, and optimum window areas of office buildings for the three cities are determined. Based on the results, the optimum window area for the north building facade for all climates is 20-30\%. This amount for the southern facade of the building in Bushehr, Shiraz, and Tabriz is, respectively, 20-30\%, 10-30\%, and 20-50\%. The optimum window area for the eastern and western building facades in Bushehr is 30-50\%; in Tabriz it is 40-70\%, and in Shiraz it is $20-60 \%$ and $40-70 \%$, respectively. The difference between the maximum and minimum energy consumption with different window areas in Bushehr and Shiraz is $20-100 \%$ and in Tabriz it is $16-25 \%$.
\end{abstract}

Keywords: window-to-wall ratio (WWR); office; solar heat gain; climate; energy consumption

\section{Introduction}

Today, about $50 \%$ of the world's population lives in cities; this proportion is expected to reach $80 \%$ by 2030 [1]. Large amounts of energy are consumed in the building sector, and cities are responsible for $70 \%$ of global carbon emissions [2,3]. In this situation, it is necessary to consider savings and reduction of energy consumption in all areas, including in buildings [4]. About $40 \%$ of energy consumption in Iran is related to buildings [5]. In some buildings, about half of the heating and cooling load is lost through windows. Meanwhile, in order to reduce the energy consumption of buildings, the insulation of walls and windows has been increasing. For this purpose, it is necessary to determine the optimum percentage of windows at different facades of the building, especially for the various climate conditions of Iran.

The optimum window-to-wall ratio (WWR) must be taken into consideration in the early stages of designing a building with respect to the form, orientation, distribution, and dimensions of the windows. The optimum WWR means the window area that minimizes the total annual energy of cooling, heating, and lighting [6]. Usually, in the design of static buildings to increase the amount of solar heat gain, at the northern facade small windows are used and at the southern facade large 
windows are utilized. The impact of increasing the northern window areas and reducing the southern windows in static buildings was examined by Persson in Gothenburg, Sweden [7]. The results of this study revealed that the dimensions of the energy-efficient window had a low impact on the heating load, but were very effective for the cooling load. Moreover, this study revealed that heat losses were very low, since the building envelope was well insulated and triple-glazed windows had been installed. This suggests that, contrary to conventional thinking in static buildings, it is possible to use large windows at the northern facade and have desirable light conditions. If the windows are used efficiently, the larger dimensions of the northern window cause a slight increase in the thermal energy and do not have much impact on the heating peak. However, when using large southern windows, the ventilation rate needs to be increased and shading devices should be utilized. In addition, the orientation towards the sun has moderate importance in increasing the indoor temperature for the window size, so no significant change in the amount of energy is obtained by rotating houses $180^{\circ}$. Meanwhile, it is worth mentioning the results from other cold climates with more solar irradiation during the winter; buildings with inadequate insulation and buildings in the shade could have different results [7].

In some studies, the impact of window type and its optical properties related to its relative area for different building types were analyzed. In this regard, the study of Goia [6] was conducted for a building in Rome. The results of this study indicated that changing the area of the window changes its optimal type. Based on the results, the optimal WWR was $35-45 \%$, which does not depend on the orientation and facade surface. The greatest difference in the energy consumption was for the best and worst configurations of the northern façade, and the smallest difference was in the southern facade. The analysis of the results revealed that the overall energy consumption of the building has a low correlation with the geometry and efficiency of the air-conditioning system, while it is highly dependent on changing the indoor heat load and the shading system. The impact of facade on energy-efficient buildings was much lower than that of conventional buildings [8]. Various studies have investigated the optimum WWR in cold climates of Europe. Meanwhile, in a new study, this ratio has been carried out for a typical office building at four different climates of Europe, from $35^{\circ}$ to $60^{\circ} \mathrm{N}$ latitude. The studied building has had advanced technology regarding envelope components and also the optimum ratio for four building facades. According to the results, for each climate with a certain orientation, there is no optimal ratio for the window size, but in all cases, the minimum energy consumption in samples was for those with a window area of 30-45\%. However, the southern facade of the cold climate and the very hot climate were exceptions. In addition, the difference in energy consumption for the best and worst cases was 5-25\% [6]. In the central European region, non-compact forms are more suitable than compact forms because they allow for using larger window surfaces and therefore allow more solar heat gain to be received. One of the best models in this climate was a square plan with $50 \%$ southern glass and without shading devices. However, for other cases, using proper shading device is essential to prevent overheating in the summer. In case of using a shading device (especially a movable shading device), energy consumption will be minimal even if large glass areas are used [9].

Various types of optimization algorithms can be used to optimize the envelope design of buildings. In simulations that were conducted with optimization, the genetic algorithm is coupled to a building engine in order to select optimal values for envelope parameters for the minimum energy consumption of buildings. Tuhus-dubrow and Krarti [10], using the genetic algorithm, investigated residential buildings that were rectangular, L-shaped, T-shaped, cross-shaped or trapezoidal, and examined the effect of the type and area of the windows. The results of this study revealed that rectangular and trapezoidal-shaped buildings have the best performance from the aspect of life-cycle and cost amongst all of the different climates. In addition, for hot climates the southern trapezoid form, and for cold climates the northern trapezoid form, are more suitable. If all variables can be changed, the square form with the minimum cost has the best performance in all climates. For the optimized parameters, the difference between the results was small, about $5 \%$. For various climatic conditions, especially the hot-humid climate, there was not enough information about the thermal performance of the 
envelope of buildings. Such a function depends on the configuration of design elements and the technical characteristics of the facades [11]. In research in Kuala Lumpur, the energy consumption of a building has been evaluated by changing the orientation, building envelope heat transfer coefficients, and window properties. The changes in the window characteristics affect the absorption of thermal energy and transfer visible light. By using regression analysis, the relationship between the window characteristics and energy consumption of the building has been analyzed and the envelope design guide was represented for five climates. Based on these results, the proposed ratio of WWR in all directions (except for the north facade in two climates) is $25 \%$. In climates 1 and 2, based on ASHRAE's division, installing window in the north, south, west, and east facades confers the most benefits. For three to five climates of ASHRAE, the highest impact was related to the south, north, west, and east facades [12].

In a parametric study, the optimal dimension of a window was investigated based on the thermal performance of a reference room located in Portugal and the parameters of opening type, orientation, and size were evaluated; then the overhangs were checked and the degree-hours of discomfort calculated. It was revealed that the northeast and west directions are inappropriate, and a triple-glazed window at the northern facade is the most appropriate. The results of this study reveal that shades do not significantly improve thermal performance but allow windows to have a wider dimensional opening [13].

Recently an extensive research effort has been carried out by means of Energy Plus software in order to measure the optimum WWR for a conventional office building based on Italian regulations. The factors investigated in this study were the thermal characteristics of the building envelope, electrical lighting of environment, and movable shadings for 12 different climates. The studied WWR ratios with $10 \%$ steps varied from $5 \%$ to $55 \%$. For all climates, the optimum WWR in a building with good insulation was $23.5 \%$; for a building with poor insulation it was $25.9 \%$. In different conditions, the optimum glass area can be doubled due to the configuration effect of the envelope characteristics and electrical lighting. For all climates, glass was a more efficient choice, and for specific glass types the maximum window area was about $32 \%$ [14].

In the study of Alghoul et al. [15], the influence of WWR and window orientation on the overall energy consumption of a small office building in Libya was investigated by means of Energy Plus software funded by the U.S. Department of Energy Building Technologies Office. The results of this study indicate that increasing the WWR between $0 \%$ and $90 \%$ increases the cooling load and reduces the heating load; in different conditions the total energy consumption of the building has been increased by $6-181 \%$. In methodologies that estimate the design parameters, the purpose is to determine the thermal requirements of a building as a dynamic thermal system. For such design its internal temperature range should not be changed more than a few degrees. Accordingly, Ma et al. [16]. have determined the maximum allowable WWR based on the thermal characteristics of the building envelope and outdoor air temperatures in seven climates of the United States. If the heat transfer coefficient can be reduced to $0.2 \mathrm{~W} / \mathrm{m}^{2}$, the window area can be increased equivalent to the green surface.

Krarti et al. [17] examined the effects of variables of building geometry, window area, and window type and perimeter area on lighting and energy consumption in four American regions. The visible light transmittance coefficient of the window and the relative window to floor area was determined in a way that had a significant impact on daylighting-induced energy savings. Hence, increasing the transmission coefficient increases the benefits of daylighting. A window area larger than $30 \%$ reduced the amount of energy saved. When using daylighting, the latitude has a relatively small effect, and in all locations a light transmittance coefficient larger than 0.3 reduced the energy returns. The purpose of larger windows in non-residential buildings is to create more daylight and a suitable view while avoiding thermal loss [18]. In addition, for using daylight, the window area should not be less than $10 \%$ of the floor area, although the optimum window size for daylight may not be the same as the optimum value for energy [19]. To determine the optimum WWR for a particular building, the characteristics of the environment and the urban topology should also be considered [9]. The location and window 
shape are also issues that should be investigated in future studies [14]. The opening position of a window area is highly important and by installing a window in the optimal location, the amount of energy loss through the thermal bridge decreases by $50 \%$ [20]. Due to the lack of information associated with the optimum WWR ratio, future studies on different types of buildings and different forms of cooling and heating systems are suggested [10].

Based on the literature review, no study has been conducted determining the optimum percentage of windows area in office buildings for the various climates of Iran. Therefore, the purpose of this study is to determine the optimum window wall ratio for the north, south, east and west facades of an office building for the three different climates of Iran, including the hot-humid climate of Bushehr, the hot-dry climate of Shiraz, and the cold climate of Tabriz.

\section{The Climate of Iran and the Studied Cities}

The first step in creating an environmentally friendly design is to determine the climatic factors of the considered region. According to the climate classification of the Coupon, Iran has four climates, hot-humid, hot-dry, mild and humid, and cold, as shown in Figure 1. In this research, the cities of Shiraz with a hot-dry climate, Tabriz with a cold climate, and Bushehr with a hot-humid climate were studied.

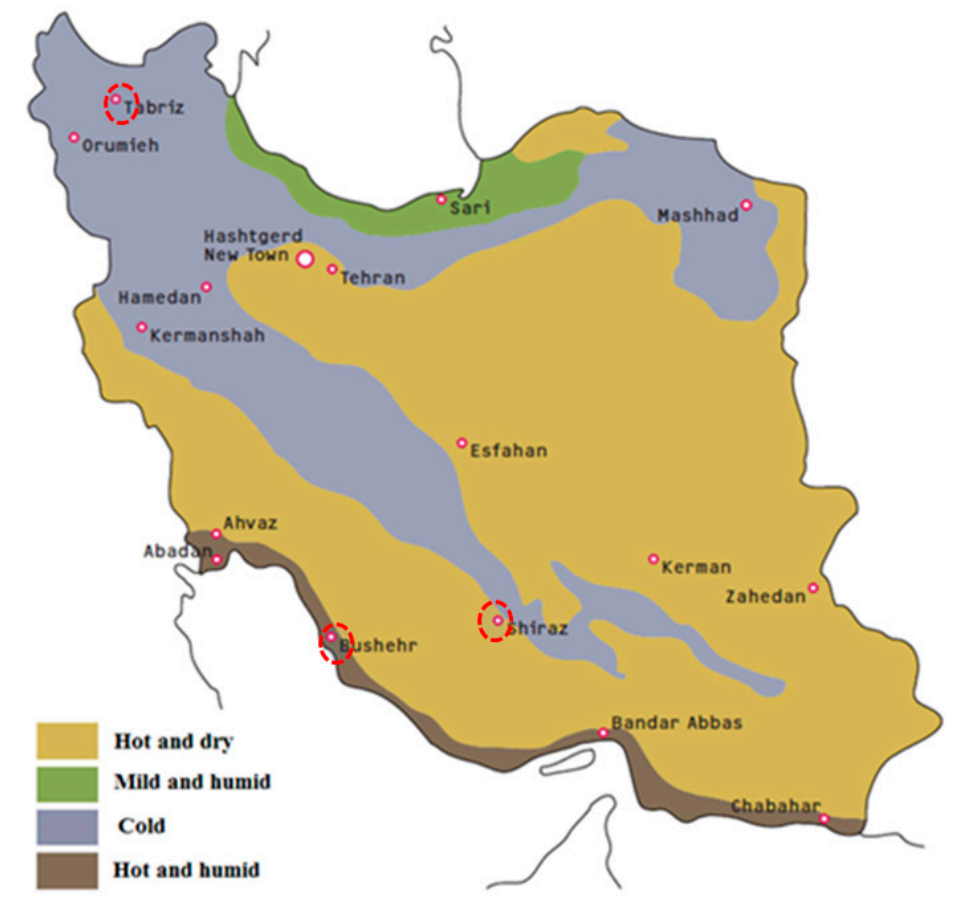

Figure 1. Climatic divisions of Iran [21].

Table 1 gives climatic data for Bushehr, Tabriz, and Shiraz.

Table 1. Case studies: climatic data.

\begin{tabular}{cccccc}
\hline City & $\begin{array}{c}\text { Prevailing Wind } \\
\text { Direction }\end{array}$ & $\begin{array}{c}\text { Average Wind } \\
\text { Speed }\end{array}$ & $\begin{array}{c}\text { Mean } \\
\text { Temperature }\end{array}$ & $\begin{array}{c}\text { Diffuse Horizontal } \\
\text { Solar Radiation }\end{array}$ & $\begin{array}{c}\text { Average Direct } \\
\text { Normal Solar } \\
\text { Radiation }\end{array}$ \\
\hline Bushehr & $\begin{array}{c}\text { north and } \\
\text { northwest }\end{array}$ & $2.5 \mathrm{~m} / \mathrm{s}$ & $25{ }^{\circ} \mathrm{C}$ & $73.3 \mathrm{kWh} / \mathrm{m}^{2}$ per year & $95.8 \mathrm{kWh} / \mathrm{m}^{2}$ per year \\
\hline Tabriz & west & $3 \mathrm{~m} / \mathrm{s}$ & $11.9^{\circ} \mathrm{C}$ & $76.7 \mathrm{kWh} / \mathrm{m}^{2}$ & $72.7 \mathrm{kWh} / \mathrm{m}^{2}$ \\
\hline Shiraz & $\begin{array}{c}\text { north and } \\
\text { northwest }\end{array}$ & $2.2 \mathrm{~m} / \mathrm{s}$ & $17.8^{\circ} \mathrm{C}$ & $110.2 \mathrm{kWh} / \mathrm{m}^{2}$ & $96.7 \mathrm{kWh} / \mathrm{m}^{2}$ \\
\hline
\end{tabular}


In Figure 2, the average monthly temperature of Tabriz, Bushehr, and Shiraz is given.

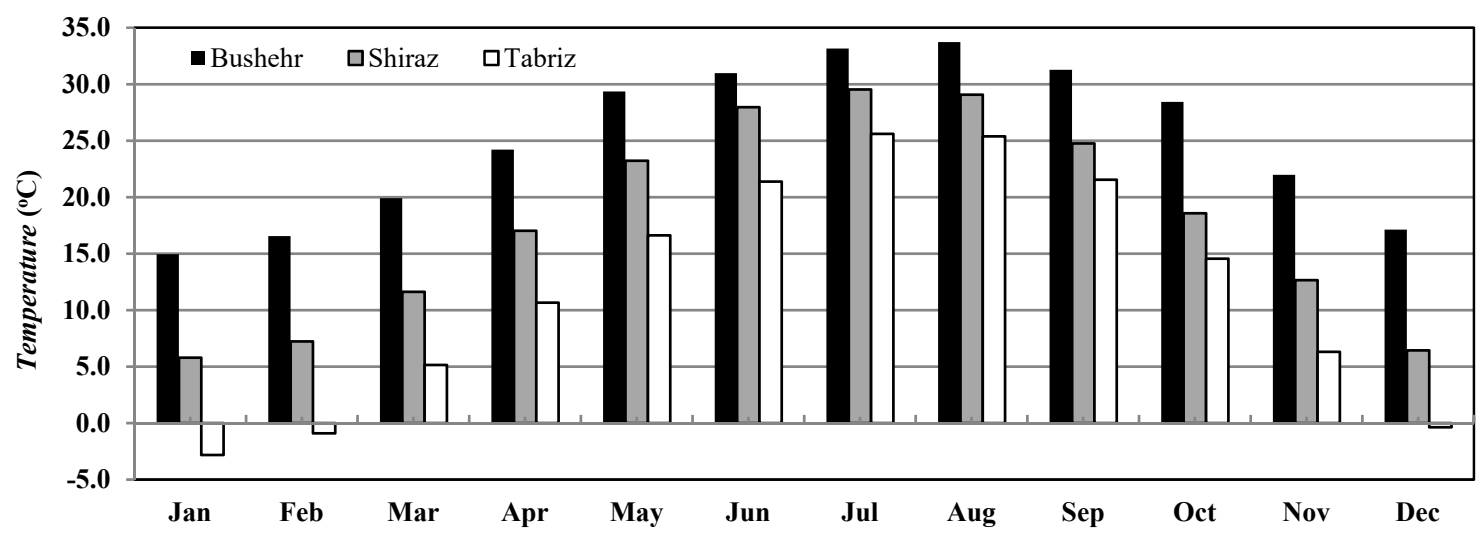

Figure 2. Average monthly temperatures of Shiraz, Tabriz, and Bushehr for the period of 2006-2016 (Data from the Iran Meteorological Organization).

\section{Methodology}

In order to determine the optimum percentage of window size in the external facades of an office building, the building dimensions were considered to be $8 \mathrm{~m} \times 16 \mathrm{~m}$ with a height of $3.5 \mathrm{~m}$; this is based on the study of Nasrollahi [4], in which the optimum percentage of windows for office buildings was determined. This building has an eastern-western orientation, as illustrated in Figure 3. In this research, DesignBuilder software [22] was used to simulate the building. This software has the Energy Plus analysis engine and is able to calculate the solar heat gain and energy consumption related to lighting, heating and cooling load. The simulated building in the DesignBuilder software is represented in Figure 3. The lighting level has been considered 400 Lux based on the ASHRAE standard.

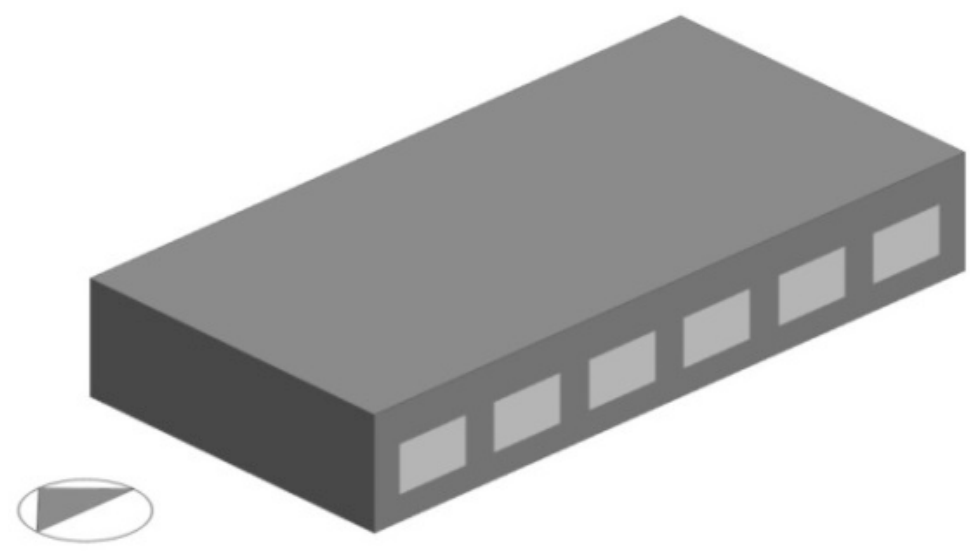

Figure 3. Simulated building in the DesignBuilder software with a 30\% window in the south façade.

In the simulation of the building, based on the ASHRAE standard, the heating setpoint was considered $22{ }^{\circ} \mathrm{C}$, and the cooling setpoint was considered $24^{\circ} \mathrm{C}$. The characteristics of the building from the aspect of orientation, occupancy rate, etc. are also represented in Table 2. 
Table 2. Characteristics of the case study.

\begin{tabular}{cc}
\hline Title & Characteristics \\
\hline Building type & Office \\
Location & Bushehr, Shiraz, Tabriz (Iran) \\
Number of floors & 1 \\
Floor height & $3.5 \mathrm{~m}$ \\
Occupation (persons $\left./ \mathrm{m}^{2}\right)$ & 7 (ASHRAE standard) \\
Office hours & $8: 00$ a.m. $-4: 00$ p.m. \\
Orientation & North-south \\
Illuminance & 400 Lux \\
\hline
\end{tabular}

In the simulated building, for double-pane glass, the thickness of each pane is $3 \mathrm{~mm}$, the thickness of the air layer between is $6 \mathrm{~mm}$, and the thermal transfer coefficient is $3.3 \mathrm{~W} / \mathrm{m}^{2} \mathrm{~K}$. Also, the window frame was made of Unplasticized Polyvinyl Chloride (UPVC). The materials used in the sample building are represented in Table 3.

Table 3. The building materials simulated in the DesignBuilder software derived from the Energy Plus software library, based on the ASHRAE standard [20].

\begin{tabular}{ccccc}
\hline & Containing Layer & Layer Thickness $(\mathbf{m m})$ & U-Value $\mathbf{W} /\left(\mathbf{m}^{\mathbf{2}} \mathbf{K}\right)$ & $\mathbf{R}_{\mathbf{c}}$-Value $\left(\mathbf{m}^{\mathbf{2}} \mathbf{K}\right) / \mathbf{W}$ \\
\hline \multirow{4}{*}{ Exterior wall } & Brickwork Outer Leaf & 100 & & \\
& XPS Extruded Polystyrene & 100 & 0.35 & 2.85 \\
& Concrete Block & 100 & & \\
Gypsum Plastering & 10 & & 2.09 \\
Roof & Asphalt & 10 & 0.47 & \\
& Fiber board & 10 & & \\
\hline
\end{tabular}

\section{Simulation}

The percentage of windows area in the four north, south, east, and west facades of the building has been investigated from $0 \%$ to $100 \%$ with a $10 \%$ step. In order to determine the optimum percentage of a building facade, at first all facades were considered windowless and then the percentage of the window on that facade was changed and the data of solar heat gain, cooling load, heating load, and the annual lighting consumption of each mode were determined.

\section{Results and Discussion}

After simulating the building, the solar heat gain, cooling, heating and lighting consumption of the building were calculated for the cities of Bushehr, Shiraz, and Tabriz.

\subsection{Solar Heat Gain}

Solar heat gain is one of the most important factors associated with the cooling load of a building, which means an increase in the temperature of a space, object, or building that is derived from solar radiation. The amount of solar heat gain increases in continued sunlight or with any mediator material that can transmit radiation or resist it. In addition, the solar heat gain coefficient is one of the most important characteristics of a window, which transmits into the total solar energy of the window and its components includes glass, materials used in the frame, etc. [23].

Figure 4 indicates the solar heat gain of the office building with different window percentages for the four facades of an office building in Bushehr, Shiraz, and Tabriz. As illustrated in Figure 4, as the window percentage increases, the solar heat gain increases because more sun radiation enters the interior. 

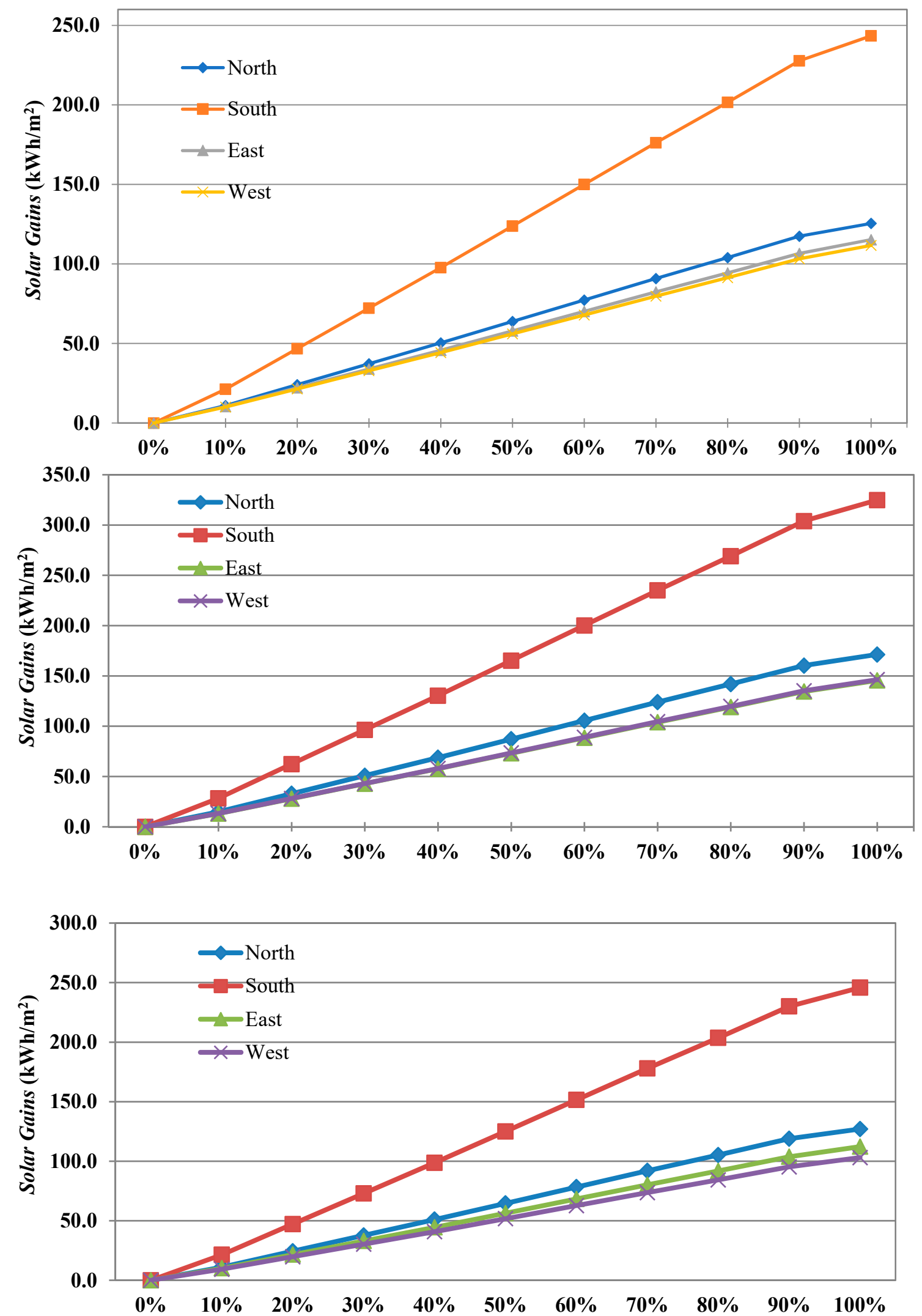

Figure 4. Annual solar heat gain of buildings with different percentages of windows at different facades for Bushehr (upper), Shiraz (middle), and Tabriz (below), Iran. 
For Bushehr, the solar heat gain of a building with a $10 \%$ window on the south facade of the building was $21.2 \mathrm{kWh} / \mathrm{m}^{2}$, and this value with $50 \%$ WWR reached $123.8 \mathrm{kWh} / \mathrm{m}^{2}$. At the northern facade of the building, the solar heat gain with $10 \%$ of the external window is $10.1 \mathrm{kWh} / \mathrm{m}^{2}$, and this amount with a $100 \%$ window will reach $125.5 \mathrm{kWh} / \mathrm{m}^{2}$ (Figure 4). The percentage of solar heat gain for the eastern and western windows is almost equal. The solar heat gain of the building with $10 \%$ and $100 \%$ windows on the east facade is $10.1 \mathrm{kWh} / \mathrm{m}^{2}$ and $111.6 \mathrm{kWh} / \mathrm{m}^{2}$, respectively. Also, the solar heat gain with $10 \%$ and $50 \%$ windows on the south facade of the building in Shiraz is $28.3 \mathrm{kWh} / \mathrm{m}^{2}$ and $165.2 \mathrm{kWh} / \mathrm{m}^{2}$, respectively (Figure 4). At the northern facade of the building, the solar heat gain with $10 \%$ and $100 \%$ external windows is $13.3 \mathrm{kWh} / \mathrm{m}^{2}$ and $171.3 \mathrm{kWh} / \mathrm{m}^{2}$. The solar heat gain for the percentage of the eastern and western windows is approximately equal. The solar heat gain of the building with $10 \%$ and $100 \%$ windows on the west facade in Shiraz is $13.2 \mathrm{kWh} / \mathrm{m}^{2}$ and $146.3 \mathrm{kWh} / \mathrm{m}^{2}$, respectively (Figure 4). The solar heat gain of the building with $10 \%$ windows at the south facade of the building in Tabriz was $21.4 \mathrm{kWh} / \mathrm{m}^{2}$ and with $100 \%$ windows the solar heat gain increased by $224.4 \mathrm{kWh} / \mathrm{m}^{2}$. At the northern facade of the building, the solar heat gain with $10 \%$ external windows is $9.3 \mathrm{kWh} / \mathrm{m}^{2}$, and this value at $100 \%$ windows is $127.1 \mathrm{kWh} / \mathrm{m}^{2}$ (Figure 4). The average solar heat gain yield for the eastern windows is $7 \%$ higher than the western windows. The solar heat gain of the building with $10 \%$ and $100 \%$ windows on the western facade is about $10 \mathrm{kWh} / \mathrm{m}^{2}$ and $10 \mathrm{kWh} / \mathrm{m}^{2}$, respectively, and this value for the east windows is $9.2 \mathrm{kWh} / \mathrm{m}^{2}$ and $103 \mathrm{kWh} / \mathrm{m}^{2}$.

\subsection{Cooling Load}

In Figure 5 the building cooling load has been illustrated with the percentage of windows for the four main facades of the building in the cities of Bushehr, Shiraz, and Tabriz. As shown in Figure 5, the north facade of the building with $20 \%$ external window has the minimum cooling load, which is $45.1 \mathrm{kWh} / \mathrm{m}^{2}$, and the maximum cooling load belongs to a $100 \%$ external window, which is $80.9 \mathrm{kWh} / \mathrm{m}^{2}$. On the south facade, the windows with ratios of $10 \%, 20 \%$, and $30 \%$, and with a mean consumption of $57 \mathrm{kWh} / \mathrm{m}^{2}$, have a minimum cooling load due to the low solar heat gain with these window percentages (Figure 5). In Bushehr, the eastern and western facades of the $10 \%$ and $20 \%$ windows, with consumption of $54.9 \mathrm{kWh} / \mathrm{m}^{2}$, had the minimum cooling load consumption.

In Shiraz the building with $10 \%$ and 30\% external windows at the northern facade and the southern facade has the minimum cooling load; in addition, the maximum cooling load belongs to the $100 \%$ external window. In the south facade, buildings with $10 \%, 20 \%$, and $30 \%$ of window have cooling loads of $50.2 \mathrm{kWh} / \mathrm{m}^{2}, 54.9 \mathrm{kWh} / \mathrm{m}^{2}$, and $65.6 \mathrm{kWh} / \mathrm{m}^{2}$, respectively. At the north facade of the building also, with $10 \%, 20 \%$, and $30 \%$ of window, the cooling loads are $50.2 \mathrm{kWh} / \mathrm{m}^{2}, 50.8 \mathrm{kWh} / \mathrm{m}^{2}$, and $57.2 \mathrm{kWh} / \mathrm{m}^{2}$, respectively. In addition, in Shiraz, the eastern and western facades of the building with $10 \%$ and $20 \%$ and the cooling load of $54.9 \mathrm{kWh} / \mathrm{m}^{2}$ have the minimum cooling load (Figure 5).

In Tabriz, the building with $10 \%$ to $30 \%$ windows on four facades has the minimum cooling load, and the maximum amount of cooling load also belonged to the $100 \%$ external window. On the south facade of a building with $10 \%, 20 \%$, and $30 \%$ windows the cooling load is $22.7 \mathrm{kWh} / \mathrm{m}^{2}, 24.5 \mathrm{kWh} / \mathrm{m}^{2}$, and $29.4 \mathrm{kWh} / \mathrm{m}^{2}$, respectively. At the north facade of the building, with $10 \%$ and $30 \%$ window, the cooling load is $22.7 \mathrm{kWh} / \mathrm{m}^{2}$ and $26.3 \mathrm{kWh} / \mathrm{m}^{2}$, respectively. The cooling load of the building for Tabriz in the east and west facades, for $10 \%, 20 \%$, and $30 \%$ windows, is $25.9 \mathrm{kWh} / \mathrm{m}^{2}$. Meanwhile, the low amount of cooling load of buildings with $10 \%$ and $20 \%$ on the south and north facades are due to low solar heat gain (Figure 5); this in turn is because less solar radiation enters the environment, resulting in a lower indoor temperature. 

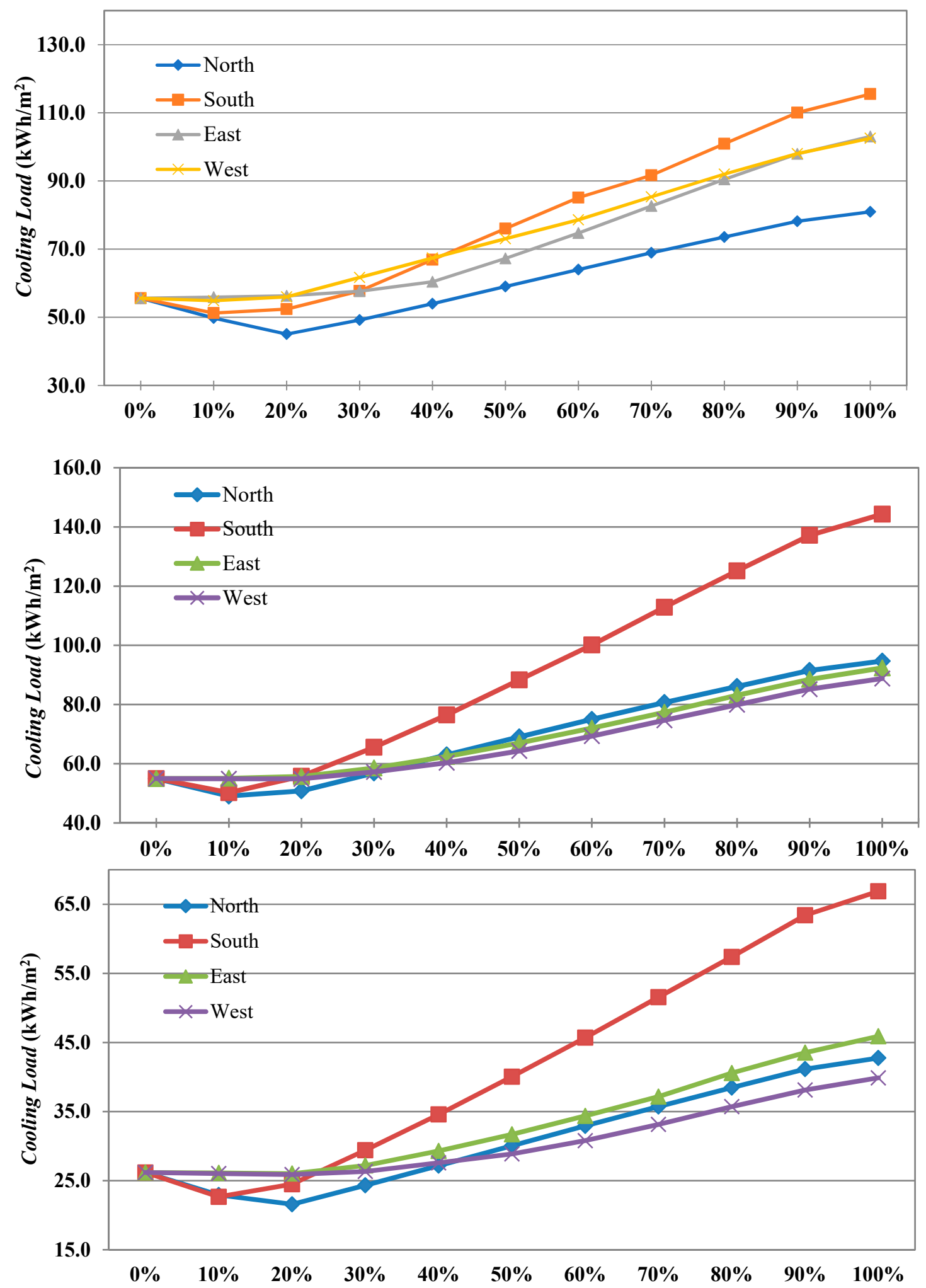

Figure 5. The amount of annual cooling load of the building with different percentages of windows at different facades for Bushehr (upper), Shiraz (middle), and Tabriz (below), Iran.

\subsection{Heating Load}

In Figure 6, the amount of heating load of the building with the percentages of windows for Bushehr, Shiraz, and Tabriz is indicated. When increasing the window percentage for the buildings in the studied cities, the heating load decreases, because more solar heat enters the indoor environment 
(Figure 6) and increases the room temperature. According to Figure 6, there is a significant difference between the cooling load of the building with 10\% and 100\% windows, and based on Figure 6 there is no significant difference between the heating load of a building with $10 \%$ and $100 \%$ windows. The results are in line with the results of Persson et al. [7], in whose study it is pointed out that the dimensions of the window do not have a significant impact on the heating load; however, it has a large effect on the cooling load. In addition, according to Figure 6, increasing the window percentage from $30 \%$ to $100 \%$ reduces the heating load due to the sunlight, which helps to increase the temperature of the room. Meanwhile, these results are unlike the results of Persson et al. [7], who mentioned that the larger dimensions of a northern window cause a slight increase in the heating load.
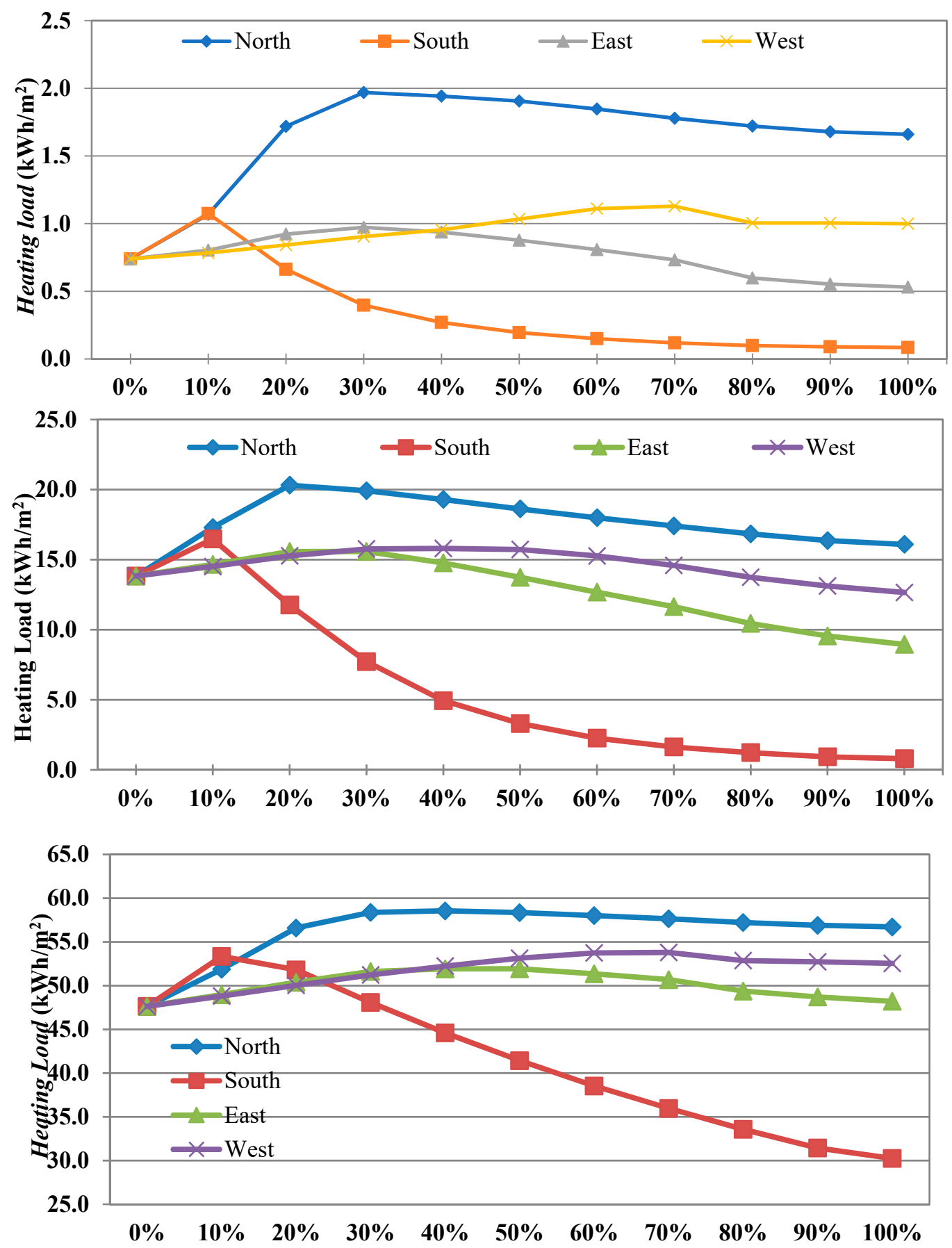

Figure 6. Annual heating load of buildings with different percentages of windows at different facades for Bushehr (upper), Shiraz (middle), and Tabriz (below), Iran. 
The north facade of the building, with a $30 \%$ window and a consumption of $2 \mathrm{kWh} / \mathrm{m}^{2}$, has the maximum consumption of heating load. In addition, the south facade of the building with a $10 \%$ window and the consumption of $1.1 \mathrm{kWh} / \mathrm{m}^{2}$ has the maximum heating load; by increasing the window percentage to $50 \%$ and $100 \%$, this amount was reduced by $0.2 \mathrm{kWh} / \mathrm{m}^{2}$ and $0.1 \mathrm{kWh} / \mathrm{m}^{2}$. Also, it was revealed that a building with $30 \%$ windows on the eastern facade and the consumption of $1 \mathrm{kWh} / \mathrm{m}^{2}$ has the maximum heating load, and this amount with the consumption of $0.5 \mathrm{kWh} / \mathrm{m}^{2}$ is reduced to a minimum by $100 \%$ windows. On the western facade of the building in Bushehr, a building with $10 \%$ windows and a consumption of $0.8 \mathrm{kWh} / \mathrm{m}^{2}$ has the minimum heating load; it reaches the maximum with a consumption of $1.1 \mathrm{kWh} / \mathrm{m}^{2}$ by a $60 \%$ window.

In Shiraz, the northern facade of the building with a $20 \%$ window and a consumption of $20.3 \mathrm{kWh} / \mathrm{m}^{2}$ has the maximum annual heating consumption, and with a $100 \%$ window it has the minimum heating load, which is $16.1 \mathrm{kWh} / \mathrm{m}^{2}$. The south facade of the building with $10 \%$ windows and a consumption of $53.3 \mathrm{kWh} / \mathrm{m}^{2}$, has the maximum heating load and the building with a $100 \%$ window in the south facade consumes the minimum amount of heating load, which is $0.8 \mathrm{kWh} / \mathrm{m}^{2}$. In Shiraz, buildings with $30 \%$ windows on the east and west facades of and with a consumption of $15.3 \mathrm{kWh} / \mathrm{m}^{2}$ have the maximum heating load and the east and west facades of the building with a $100 \%$ window have the minimum heating load with consumption of $9 \mathrm{kWh} / \mathrm{m}^{2}$ and $12.7 \mathrm{kWh} / \mathrm{m}^{2}$.

In Tabriz, the building with $30 \%$ window on the northern facade has a consumption of $56.8 \mathrm{kWh} / \mathrm{m}^{2}$, which is the maximum consumption of heating load. In addition, the building with a $10 \%$ window and a consumption of $53.3 \mathrm{kWh} / \mathrm{m}^{2}$ on the northern facade has the minimum heating load; this is because a lower amount of heat is transmitted through the windows. Also, the south facade of the building with $10 \%$ window and consumption of $53.3 \mathrm{kWh} / \mathrm{m}^{2}$ has the maximum heating load; increasing the window percentage to $100 \%$ would decrease this amount to $30.3 \mathrm{kWh} / \mathrm{m}^{2}$. In Tabriz, at the eastern facade, the maximum and minimum heating loads are $40 \%$, with a consumption of $52.5 \mathrm{kWh} / \mathrm{m}^{2}$, and $10 \%$ and $48.8 \mathrm{kWh} / \mathrm{m}^{2}$, due to the angle of sun radiation in Tabriz. Also, in the west facade, the maximum and minimum heating load is $70 \%$ with a consumption of $53.8 \mathrm{kWh} / \mathrm{m}^{2}$ and $10 \%$ with a consumption of $48.8 \mathrm{kWh} / \mathrm{m}^{2}$, respectively.

\subsection{Lighting Consumption}

In Figure 7, the annual lighting consumption of the building for various window percentages is illustrated for the cities of Bushehr, Shiraz, and Tabriz. According to Figure 7, when increasing the percentage of windows in all facades, the amount of light consumption decreased because more natural light entered the indoor environment, which leads to a decrease in lighting consumption.

In Bushehr, the annual lighting consumption of a building with $10 \%$ windows on the south and north facade is $15.7 \mathrm{kWh} / \mathrm{m}^{2}$ and $22.4 \mathrm{kWh} / \mathrm{m}^{2}$, respectively, while at $30 \%$ external windows it reaches $5.3 \mathrm{kWh} / \mathrm{m}^{2}$. In the northern and southern facades, the lighting consumption above the $30 \%$ window is almost constant. Also, the annual lighting amount of a building with $10 \%$ external windows on the east and west facade is approximately $33.3 \mathrm{kWh} / \mathrm{m}^{2}$, adjusted to $6.9 \mathrm{kWh} / \mathrm{m}^{2}$ with a $60 \%$ window.

In Shiraz, buildings with $10 \%$ windows at all facades have the most lighting consumption. The $10 \%$ windows on the north and south facades led to a consumption of $18.8 \mathrm{kWh} / \mathrm{m}^{2}$ and $11 \mathrm{kWh} / \mathrm{m}^{2}$, respectively. Also, a $10 \%$ window on the east and west facade has consumed $31.7 \mathrm{kWh} / \mathrm{m}^{2}$. In the north and south facades, windows above $20 \%$ have almost the same performance, which causes a lighting consumption of $4 \mathrm{kWh} / \mathrm{m}^{2}$, and in the east and west facades, windows above $60 \%$ have the same lighting consumption and do not significantly change (Figure 7).

In Tabriz, buildings with $10 \%$ windows in all facades have the maximum lighting consumption. The $10 \%$ windows on the north and south facades have led to a lighting consumption of $25.3 \mathrm{kWh} / \mathrm{m}^{2}$ and $14.1 \mathrm{kWh} / \mathrm{m}^{2}$, respectively, and have consumed $34.9 \mathrm{kWh} / \mathrm{m}^{2}$ on the east and west facades. In Tabriz, the lighting of a building with a window above $40 \%$ on the northern and southern facades is almost the same, which results in a lighting consumption of $4.1 \mathrm{kWh} / \mathrm{m}^{2}$. On the east and west facades, windows above $70 \%$ have almost the same lighting consumption, $5.8 \mathrm{kWh} / \mathrm{m}^{2}$. 

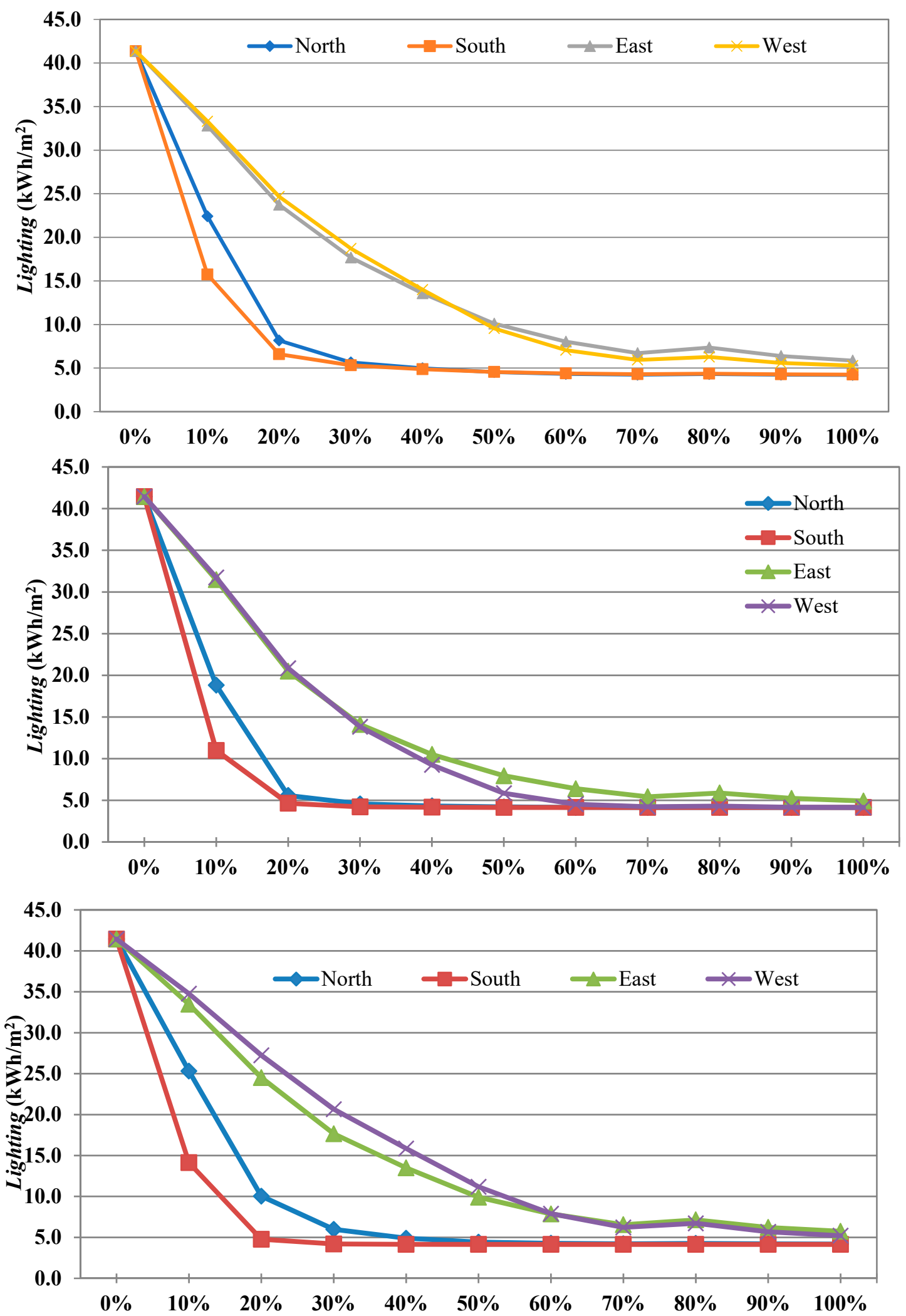

Figure 7. Annual lighting consumption of buildings with different percentages of windows in different facades for Bushehr (upper), Shiraz (middle), and Tabriz (below), Iran. 


\subsection{Total Loads of Cooling, Heating, and Lighting Consumption}

In Figure 8, the total amount of cooling, heating, and lighting consumption of the building with different percentages of windows in the north, south, east, and west facades are shown for the cities of Bushehr, Shiraz and Tabriz.
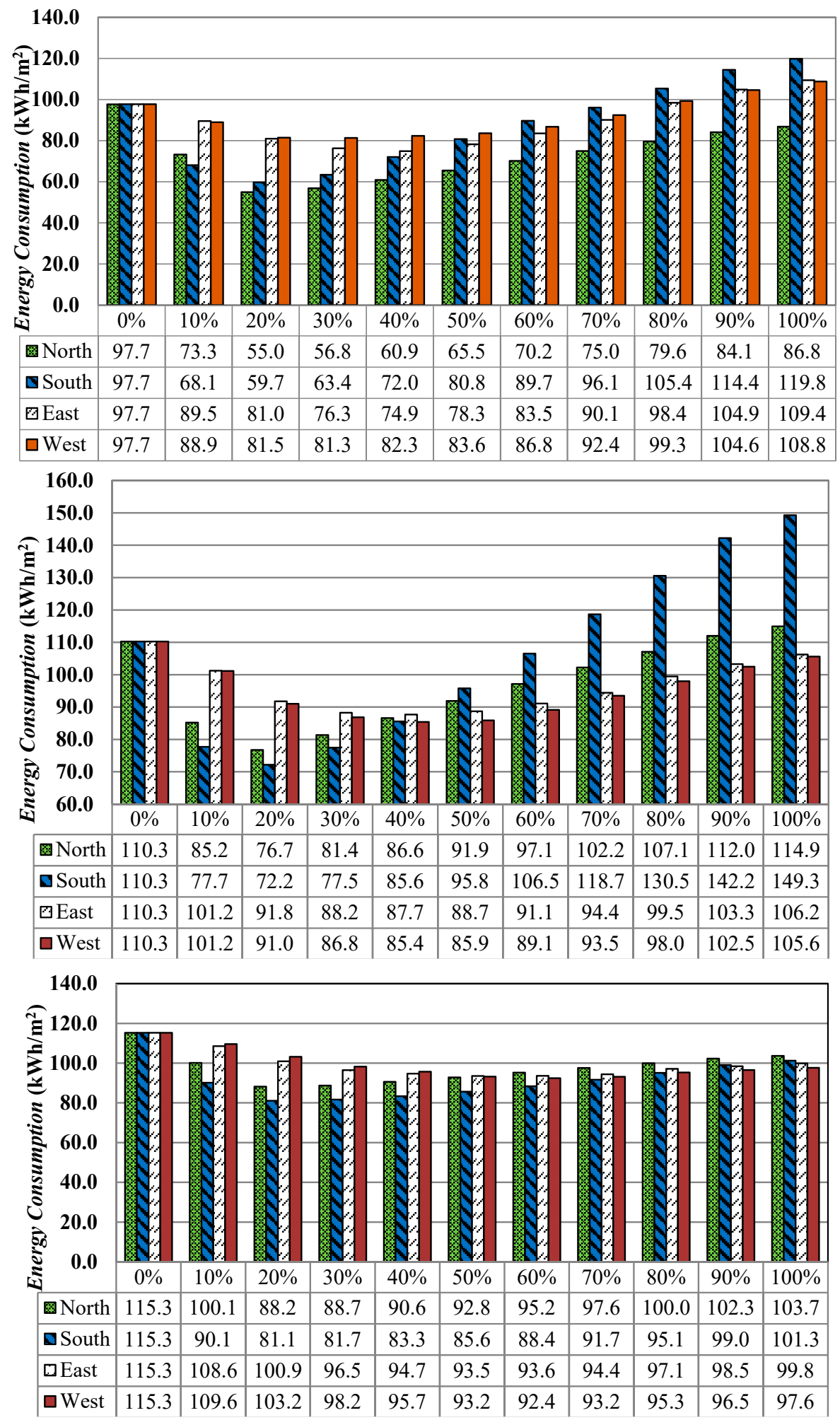

Figure 8. Annual total cooling, heating, and lighting loads of buildings with different percentages of windows at different facades in Bushehr (upper), Shiraz (middle), and Tabriz (below), Iran. 
As shown in Figure 8 in Bushehr, the building with windows on the northern facade had the minimum energy consumption of $20 \%$ to $40 \%$. The building with $20 \%$ windows consumes $55 \mathrm{kWh} / \mathrm{m}^{2}$, and the amount for $30 \%$ and $40 \%$, is, respectively, $56.8 \mathrm{kWh} / \mathrm{m}^{2}$ and $60.9 \mathrm{kWh} / \mathrm{m}^{2}$. In addition, for the southern facade of the building with window percentages of $20 \%$ and $30 \%$, the energy consumption is $59.7 \mathrm{kWh} / \mathrm{m}^{2}$ and $63.4 \mathrm{kWh} / \mathrm{m}^{2}$, respectively, which is the minimum annual energy consumption for Bushehr. Also, at the east facade, for $30 \%$ and $40 \%$ of windows, respectively, the consumption was $76.3 \mathrm{kWh} / \mathrm{m}^{2}$ and $74.9 \mathrm{kWh} / \mathrm{m}^{2}$, which is the minimum annual energy consumption. On the west facade, office building with $20 \%$ and $30 \%$ with a consumption of $81.5 \mathrm{kWh} / \mathrm{m}^{2}$ and $81.3 \mathrm{kWh} / \mathrm{m}^{2} \mathrm{had}$ the minimum annual energy consumption. Considering the optimum window percentage in Bushehr, the data achieved from the south and west facades are in line with the results of Lee et al. [12], who estimate the optimum window proportions for the south, east, and west facades in the hot-humid climate of Indonesia to be $25 \%$. Regarding the 30-40\% optimum percentages of windows on the east facade of the building in Bushehr, it was revealed that these data show a 5-15\% difference from the results of Lee et al. [12], which, according to the angles and sides of the sun, is different for cities.

In Shiraz, for a building with 20-40\% windows, the northern facade had the minimum energy consumption. The energy consumption of the office building for the $20 \%, 30 \%$, and $40 \%$ windows on the northern facade is $76.7 \mathrm{kWh} / \mathrm{m}^{2}, 81.4 \mathrm{kWh} / \mathrm{m}^{2}$, and $86.6 \mathrm{kWh} / \mathrm{m}^{2}$, respectively. In addition, on the south facade of the building, $20 \%$ and $30 \%$ of the buildings had the minimum annual energy consumption, respectively, of $72.2 \mathrm{kWh} / \mathrm{m}^{2}$ and $77.5 \mathrm{kWh} / \mathrm{m}^{2}$. On the east and west facades, the $30-50 \%$ window has the minimum annual energy consumption. The energy consumption of the building on the east facade for the $30 \%, 40 \%$, and $50 \%$ windows is $88.2 \mathrm{kWh} / \mathrm{m}^{2}, 87.7 \mathrm{kWh} / \mathrm{m}^{2}$, and $88.8 \mathrm{kWh} / \mathrm{m}^{2}$, respectively. Also, the energy consumption of the western facade of the building with $30 \%, 40 \%$, and $50 \%$ of windows is $86.8 \mathrm{kWh} / \mathrm{m}^{2}, 85.4 \mathrm{kWh} / \mathrm{m}^{2}$, and $85.9 \mathrm{kWh} / \mathrm{m}^{2}$, respectively. The results of this study for Shiraz with an optimality of $30-45 \%$ windows is in line with the research of Goia et al. (2013) and Košir et al. (2017) [8,9] due to the optimum 50\% windows. Also, the results of this study for Shiraz on the southern facade were in line with the research of Marino et al. (2017) [14], which revealed that the optimum window proportion for all facades was $23.5 \%$, but for the east, west, and north facades there was a difference of $6.5-26.5 \%$.

In Tabriz, the minimum building energy consumption for the northern facade is $20 \%$ and $30 \%$, respectively, which are $88.2 \mathrm{kWh} / \mathrm{m}^{2}$ and $88.7 \mathrm{kWh} / \mathrm{m}^{2}$ (Figure 8 ). Additionally, the south facade of the building had the minimum energy consumption of buildings with $20-60 \%$ windows. The energy consumption of buildings for $20 \%, 30 \%, 40 \%, 50 \%$, and $60 \%$ of the southern facade is $81.1 \mathrm{kWh} / \mathrm{m}^{2}$, $81.7 \mathrm{kWh} / \mathrm{m}^{2}, 83.3 \mathrm{kWh} / \mathrm{m}^{2}, 85.6 \mathrm{kWh} / \mathrm{m}^{2}$, and $88.4 \mathrm{kWh} / \mathrm{m}^{2}$, respectively. Also, the east facade with $50 \%$ and $60 \%$ windows, respectively, and with a consumption of $93.5 \mathrm{kWh} / \mathrm{m}^{2}$ and $93.6 \mathrm{kWh} / \mathrm{m}^{2}$; and the west facade with $60 \%$ windows and a consumption of $92.4 \mathrm{kWh} / \mathrm{m}^{2}$ had the minimum annual energy consumption (Figure 8). The results of the research for the southern facade in Tabriz were in line with the study of Goia (2016), in which the optimum window proportion for the cold climate of Europe is considered to be $30-45 \%$. However, the data from this study for the north, east, and west facades in Tabriz show a discrepancy of 15-25\% from the results of Goia (2016), due to the difference in latitude and longitude because of the height and side of the sun and its radiation patterns.

\section{Conclusions}

In this research, the optimum percentage of windows for the north, south, east, and west facades of an office building was determined for Bushehr (with a hot-humid climate), Shiraz (with a hot-dry climate), and Tabriz (with a cold climate). Moreover, the same type of building, with the same electrical setup, mechanical setup, and materials, was used in all climate zones to standardize the research. A simulation was conducted through DesignBuilder software, and the solar heat gain, cooling load, heating load, and lighting consumption of the building were calculated in different states. All the software parameters were set to thermal comfort and energy savings based on ASHRAE standard; 
in DesignBuilder the operative temperature and setpoint were inserted separately and these values are not the same so it would be clear that the software automatically and dynamically set the default values. This means that the recorded operative temperature and setpoint are not equal. For the purposes of this paper, we only dealt with energy savings issues. A summary of our results is as follows:

1. In Bushehr, at the north facade of the building, window percentages of $20-40 \%$ gave the minimum energy consumption. In addition, the south facade of the building with a $20 \%$ and $30 \%$ window and with energy consumption of $59.7 \mathrm{kWh} / \mathrm{m}^{2}$ and $63.4 \mathrm{kWh} / \mathrm{m}^{2}$ had the minimum annual energy consumption in Bushehr. Also, the east facades, with $30 \%$ and $40 \%$ and consumption of $76.3 \mathrm{kWh} / \mathrm{m}^{2}$ and $74.9 \mathrm{kWh} / \mathrm{m}^{2}$, respectively; and the west facade with $20 \%$ and $30 \%$ and consumption of $81.5 \mathrm{kWh} / \mathrm{m}^{2}$ and $81.3 \mathrm{kWh} / \mathrm{m}^{2}$, respectively, have the minimum annual energy consumption.

2. In Shiraz, the building with $20-40 \%$ windows on the north facade had the minimum energy consumption. In addition, at the southern front of the building, $20 \%$ and $30 \%$ windows had the minimum annual energy consumption of $72.2 \mathrm{kWh} / \mathrm{m}^{2}$ and $77.5 \mathrm{kWh} / \mathrm{m}^{2}$, respectively. On the east and west facades, 30-50\% windows had the minimum annual energy consumption.

3. In Tabriz, the building's minimum energy consumption for the northern facade with $20 \%$ and $30 \%$ windows is, respectively, $88.2 \mathrm{kWh} / \mathrm{m}^{2}$ and $88.7 \mathrm{kWh} / \mathrm{m}^{2}$. The southern facade of the building had the minimum energy consumption at 20-60\% windows. Also, the east facade, with $50 \%$ and $60 \%$ windows and consumption of $93.5 \mathrm{kWh} / \mathrm{m}^{2}$ and $92.4 \mathrm{kWh} / \mathrm{m}^{2}$, and the west facade with $60 \%$ windows and consumption of $92.4 \mathrm{kWh} / \mathrm{m}^{2}$, had the minimum annual energy consumption.

Hence, due to the high consumption of energy in the building sector and because half of the energy used in buildings is wasted through the windows, the results of this study revealed the optimum window percentages for office buildings in the investigated climates of Iran. For future research, it is suggested to investigate the optimum glass in the climate of Iran and determine its type for different climates.

Author Contributions: Conceptualization, J.S. and A.C.; Formal analysis, A.C.; Methodology, A.H. and M.Y.; Resources, J.S.; Supervision, A.H. and M.Y.; Validation, J.S.; Visualization, A.C.; Writing—original draft, J.S.; Writing-review \& editing, A.H. and A.C.

Funding: This research received no external funding.

Conflicts of Interest: The authors declare no conflict of interest.

\section{References}

1. Moonen, P.; Defraeye, T.; Dorer, V.; Blocken, B.; Carmeliet, J. Urban Physics: Effect of the micro-climate on comfort, health and energy demand. Front. Archit. Res. 2012, 1, 197-228. [CrossRef]

2. Vega-Azamar, R.E.; Glaus, M.; Hausler, R.; Oropeza-García, N.A.; Romero-López, R. An emergy analysis for urban environmental sustainability assessment, the Island of Montreal, Canada. Landsc. Urban Plan. 2013, 118, 18-28. [CrossRef]

3. Shaeri, J.; Yaghoubi, M.; Alilabadi, M.; Vakilinazhad, R. Experimental Study of temperature, relative humidity and wind speed of traditional houses at hot and humid climate of Iran (Case study: Tabib and Nozari houses in Bushehr). Honar-Ha-Ye-Ziba Memari-va-Shahrsazi 2018, 23, 93-105.

4. Nasrollahi, F. Office Buildings Energy Efficient: Energy Efficiency with the Architectural Design; Berlin University: Berlin, Germany, 2015.

5. Shaeri, J.; Yaghoubi, M.; Aliabadi, M.; Vakilinazhad, R. Analysis of using nano aerogel glazing on solar heat gain and cooling load in an office at hot and dry, hot and humid and cold climates of Iran. J. Solid Fluid Mech. 2017, 7, 209-221.

6. Goia, F. Search for the optimal window-to-wall ratio in office buildings in different European climates and the implications on total energy saving potential. Sol. Energy 2016, 132, 467-492. [CrossRef]

7. Persson, M.; Roos, A.; Wall, M. Influence of window size on the energy balance of low energy houses. Energy Build. 2006, 38, 181-188. [CrossRef] 
8. Goia, F.; Haase, M.; Perino, M. Optimizing the configuration of a façade module for office buildings by means of integrated thermal and lighting simulations in a total energy perspective. Appl. Energy 2013, 108, 515-527. [CrossRef]

9. Košir, M.; Gostiša, T.; Kristl, Ž. Influence of architectural building envelope characteristics on energy performance in Central European climatic conditions. J. Build. Eng. 2017. [CrossRef]

10. Tuhus-dubrow, D.; Krarti, M. Genetic-algorithm based approach to optimize building envelope design for residential buildings. Build. Environ. 2010, 45, 1574-1581. [CrossRef]

11. Halawa, E.; Gha, A.; Gha, A.; Trombley, J.; Hassan, N.; Baig, M.; Azzam, M. A review on energy conscious designs of building façades in hot and humid climates: Lessons for (and from) Kuala Lumpur and Darwin. Renew. Sustain. Energy Rev. 2017. [CrossRef]

12. Lee, J.W.; Jung, H.J.; Park, J.Y.; Lee, J.B.; Yoon, Y. Optimization of building window system in Asian regions by analyzing solar heat gain and daylighting elements. Renew. Energy 2013, 50, 522-531. [CrossRef]

13. Amaral, A.R.; Rodrigues, E.; Gaspar, A.R.; Gomes, Á. A thermal performance parametric study of window type, orientation, size and shadowing effect, Sustain. Cities Soc. 2016. [CrossRef]

14. Marino, C.; Nucara, A.; Pietrafesa, M. Does window-to-wall ratio have a signi fi cant e ff ect on the energy consumption of buildings? A parametric analysis in Italian climate conditions. J. Build. Eng. 2017, 13, 169-183. [CrossRef]

15. Alghoul, S.K.; Rijabo, H.G.; Mashena, M.E. Energy consumption in buildings: A correlation for the influence of window to wall ratio and window orientation in Tripoli, Libya. J. Build. Eng. 2017, 11, 82-86. [CrossRef]

16. Ma, P.; Wang, L.; Guo, N. Maximum window-to-wall ratio of a thermally autonomous building as a function of envelope U-value and ambient temperature amplitude. Appl. Energy 2015, 146, 84-91. [CrossRef]

17. Krarti, M.; Erickson, P.M.; Hillman, T.C. A simplified method to estimate energy savings of artificial lighting use from daylighting. Build. Environ. 2005, 40,747-754. [CrossRef]

18. Bruno, R. Optimization of glazing systems in non-residential buildings: The role of the optical properties of air-conditioned environments. Build. Environ. 2017. [CrossRef]

19. The National Board of Housing Building and Planning, Karlskrona. Available online: http://www.boverket.se (accessed on 2 February 2019).

20. Misiopecki, C.; Bouquin, M.; Gustavsen, A.; Jelle, B.P. Thermal modeling and investigation of the most energy-efficient window position. Energy Build. 2017. [CrossRef]

21. Shaeri, J.; Yaghoubi, M.; Habibi, A. Influence of Iwans on the Thermal Comfort of Talar Rooms in the Traditional Houses: A Study in Shiraz, Iran. Buildings 2018, 8, 81. [CrossRef]

22. DesignBuilder Software Ltd. Available online: https://www.designbuilder.co.uk/ (accessed on 16 April 2017).

23. Baenas, T.; Machado, M. On the analytical calculation of the solar heat gain coefficient of a BIPV module. Energy Build. 2017, 151, 146-156. [CrossRef] 